\title{
Specific Differences in the Gonadial Spicules of Echinus esculentus (Linnæus) and Psammechinus miliaris (Gmelin).
}

\author{
By \\ Ruth Rawlinson, B.Sc., \\ Department of Zoology, Liverpool University.
}

With 4 Figures in the Text.

THE observations here recorded were made as a result of a suggestion by Professor Orton. While examining material of Psammechinus miliaris he noted the presence of $\mathrm{C}$-shaped spicules in the gonad. He kindly passed the material on to me, suggesting that an examination of other common Echinoids might prove interesting.

In searching through the relevant literature no record was found of the occurrence of gonadial spicules in E. esculentus or P. miliaris, two of our commonest Echinoids, whose specific characters are carefully described by Mortensen (5). Such spicules are, however, recorded by Mortensen (1) and Stewart (2 and 3 ) in several forms, including Temnopleurus, Stephanocidaris and Salmacis by the former and Echinostrephus, Dorocidaris and Echinus sphcera by the latter.

Living P. miliaris were obtained from Plymouth, Whitstable and Millport, spirit specimens from Plymouth, Port Erin and the River Mersey Bar Lightship ; living E. esculentus from Millport and Port Erin and preserved material from Plymouth and Port Erin. A small portion of the genital gland was removed and cleared in glycerine. The arrangement and shape of the spicules is thus rendered distinct. Approximately 100 specimens of $P$. miliaris and 36 of $E$. esculentus have been examined in this way. In both forms the spicules are situated all over the surface of the gonad ( $(0$ and ) $)$ with their tips penetrating the gland like a series of either "staples" or "calipers "(Fig. 1). In P. miliaris the majority are C-shaped with a distinct bulging in the middle of the arc on its inner and outer margins (Fig. 2), whereas the majority in E. esculentus are $\mathrm{C}$-shaped but without the central bulging (Fig. 3). Although the general form of the spicules in E. esculentus and P. miliaris is that of an are, several variations may occur. In both forms the degree of curvature varies considerably. A slight bulging in the middle of the arc on the outer 
margin is exhibited by certain spicules of $E$. esculentus, while others, although few in number (approximately 12 in a 1000 spicules examined), present a bulging in the middle of the are on the inner margin also ; thus they resemble the knobbed spicules of $P$. miliaris. In the latter animal some spicules (18 in 200 examined) are smooth crescents like those of

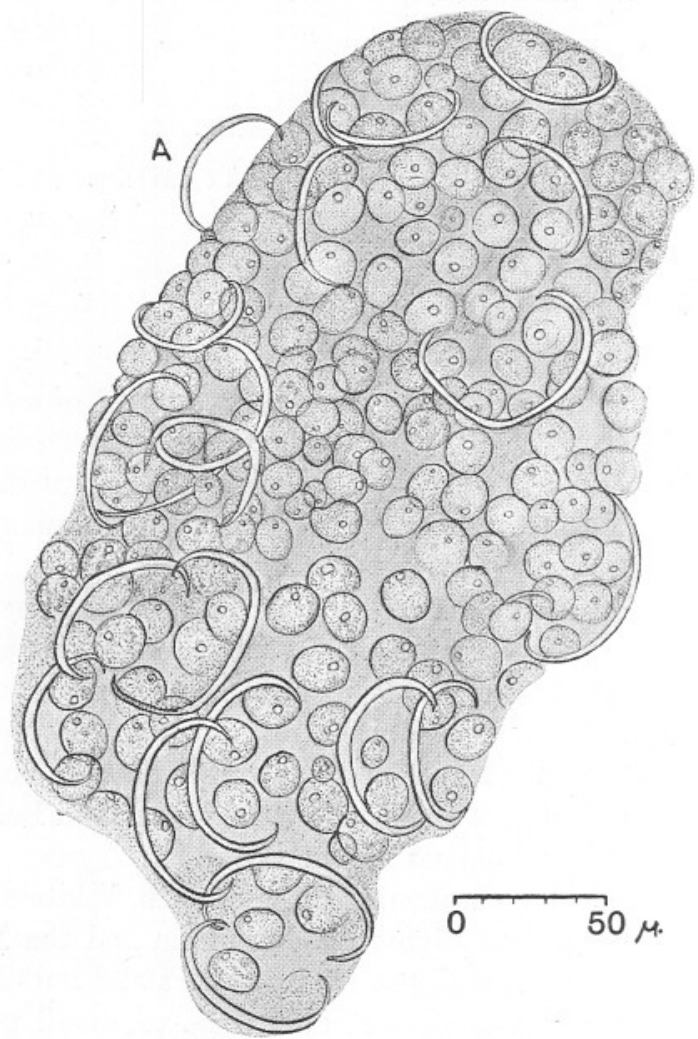

FIG. 1.-A portion of the gonad (ㅇ) of Echinus esculentus cleared in glycerine to show arrangement of spicules. (Spicule $\mathrm{A}$ has been added here in profile from another view.)

E. esculentus and others, particularly the "caliper" type, lack the inner bulging. Triradiate forms with the three rays of almost equal length may also occur in P. miliaris (approximately 15 in a 1000 spicules examined) and one has been seen in E. esculentus. In P. miliaris an unusual enlargement of the central knob on its outer margin was however observed in certain spicules of the normal type from all the localities mentioned, although particularly in animals from the River Mersey, These are apparently stages in the development of triradiate spicules. All degrees 
in the development of this enlargement were noted. In some it was slight, in others it was a definite ray, but only half the usual length, while a few spicules were triradiate with the three rays of equal length. S-shaped spicules may be present in both species, and forms with bifurcated tips were present in the Whitstable specimens of $P$. miliaris. Although these variations do occur and both species possess similarly shaped spicules, but in very different proportions, it may be said that approximately $99 \%$ of those in E. esculentus are smooth crescents whereas approximately $85 \%$ in $P$. miliaris exhibit a bulging in the middle of the arc in its inner and outer margins.

Size offers a further distinction between the gonadial spicules of these two species. In P. miliaris the mean value is $27 \mu$ and in E. esculentus $50 \mu$, the measurements given being the outside measurement across the long axis of the are of 1204 spicules taken from 54 P. miliaris (2 Plymouth, 12 Whitstable, 20 Port Erin, and 20 River Mersey specimens) ; and 1058 spicules from 15 individuals of $E$. esculentus (2 from Plymouth and 13 from Port Erin). (See Fig. 4.) In E. esculentus the range in size of the spicules is also greater than in P. miliaris. The size range appears to vary but little with the size of the individual. (See Table I.) In addition to the samples given in the table, about 20 specimens of $E$. esculentus from Port Erin showed gonadial spicules with an average length of approximately $50 \mu$.

\section{TABLE I.}

\begin{tabular}{|c|c|c|c|c|c|c|}
\hline & $\begin{array}{c}\text { No. of } \\
\text { individuals. }\end{array}$ & Locality. & $\begin{array}{l}\text { Range in } \\
\text { diameter } \\
\text { of test. }\end{array}$ & $\begin{array}{l}\text { No.* of } \\
\text { spicules } \\
\text { measured. }\end{array}$ & $\begin{array}{l}\text { Range } \\
\text { in size } \\
\text { of } \\
\text { spicules. }\end{array}$ & $\begin{array}{l}\text { Average } \\
\text { size of } \\
\text { spicules. }\end{array}$ \\
\hline$P$. miliaris & $\begin{array}{l}20 \\
90\end{array}$ & Port Erin & $0 \cdot 6-1 \cdot 2 \mathrm{~cm}$. & $\begin{array}{l}402 \\
400\end{array}$ & $\begin{array}{l}14-40 \mu \\
16-58 u\end{array}$ & $\begin{array}{l}25 \cdot 9 \mu \\
30 \cdot 0 \mu\end{array}$ \\
\hline ,", & $\begin{array}{r}20 \\
5\end{array}$ & $\begin{array}{l}\text { R. Mersey } \\
\text { Plymouth }\end{array}$ & $\begin{array}{l}1 \cdot 6-2 \cdot 5 \quad, \\
1 \cdot 7-5 \cdot 4 \quad,\end{array}$ & $\begin{array}{l}400 \\
424\end{array}$ & $\begin{array}{l}16-58 \mu \\
16-48 \mu\end{array}$ & $23 \cdot 9 \mu$ \\
\hline , & 7 & Millport & $2 \cdot 7-3 \cdot 8$, & 200 & $17-59 \mu$ & $28 \cdot 6 \mu$ \\
\hline ,, & 12 & Whitstable & $3 \cdot 0-4 \cdot 6$, & 302 & $16-53 \mu$ & $27 \cdot 8 \mu$ \\
\hline E. csculentus & 3 & Port Erin & $1 \cdot 4-2$, & 100 & $32-76 \mu$ & $43 \cdot 7 \mu$ \\
\hline, & 5 & Millport & $7 \cdot 3-9 \cdot 0$, & 200 & $32-74 \mu$ & $48 \cdot 7 \mu$ \\
\hline , & 13 & Port Erin & $7-10$, & 858 & $22-80 \mu$ & $47 \cdot 3 \mu$ \\
\hline , , & 2 & Plymouth & $\begin{array}{c}\text { larger than } \\
10 \mathrm{~cm} .\end{array}$ & 200 & $28-78 \mu$ & $49 \cdot 1 \mu$ \\
\hline
\end{tabular}

* (Only a proportion of the spicules were used for the graphs in Fig. 4.)

The average size of the spicules in $P$. miliaris taken from the five localities given above would indicate that size is doubtfully correlated with the size of the individual. A definite statement cannot be made concerning this relationship until specimens of all sizes have been examined from each locality. It may be that a particular locality has an approximately constant average size of spicule for all its individuals, large and small; or it is possible that the average size of the 


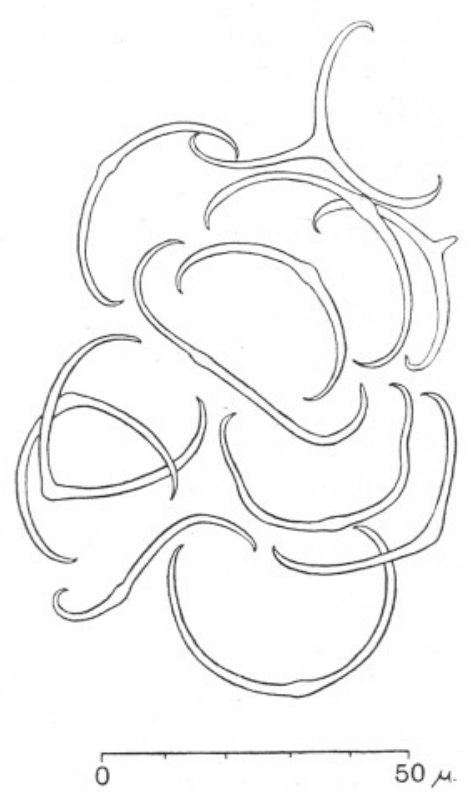

FuG. 2.- Spicules from the gonad of Psammechinus miliaris.

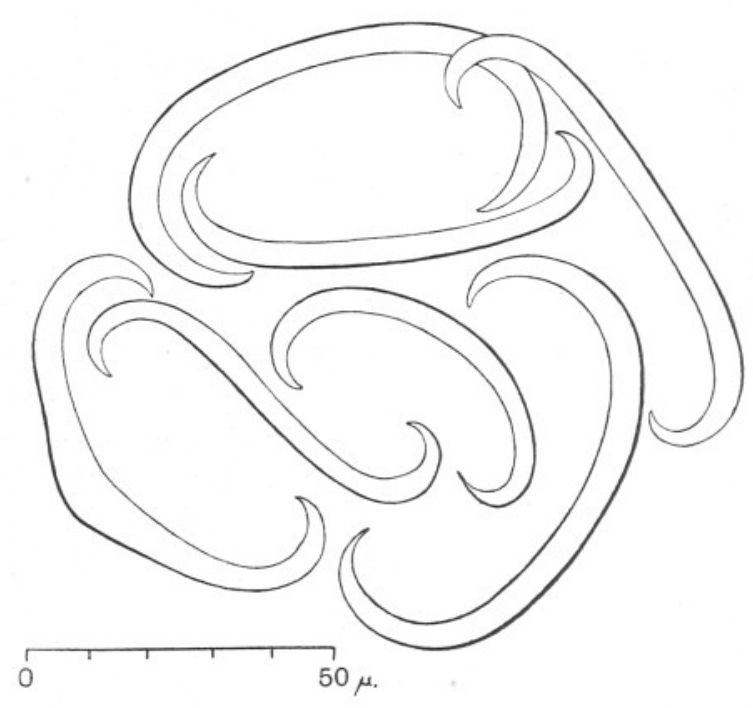

Fig. 3.-Spicules from the gonad of Echinus esculentus.

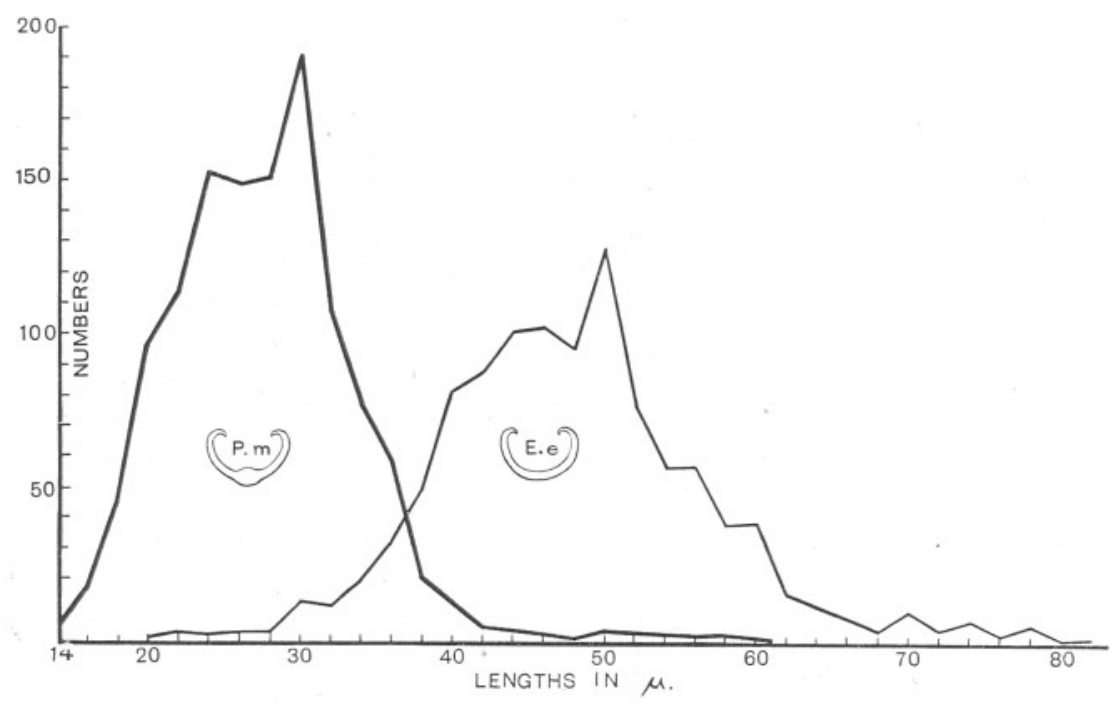

Fig. 4.-Graphs showing the variations in the lengths of 1204 unselected gonadial spicules of P. miliaris (thick lined P.m) and 1058 unselected gonadial spicules of E. esculentus (thin lined E.e) measured to the nearest $2 \mu$ and plotted on the same base. 
spicules may be correlated with the size of the individual in a particular locality. In the case of $E$. esculentus the larger specimens examined have spicules with a somewhat greater average length than the smaller ones, nevertheless the size range differs only slightly in the two sets of individuals.

In the spent gonads of both types studied the spicules are very numerous and more obvious than in the ripe gland. In this connexion it is interesting to quote a sentence from Stewart (4) in his paper on Dorocidaris in which he says, "I find great variation in the number of spicules although their general form is constant in similar specimens, those having comparatively small genital tubules having spicules most abundant, whereas where the tubules are of large size (female?) the spicules are often very scanty and small." If the number of gonadial spicules is constant, it would follow that they would be more difficult to find in the large ripe organ than in the compact spent gland.

The knobbed spicules of $P$. miliaris resemble the gonadial spicules of Echinus sphara figured by Stewart (2). Since Echinus sphcera (Müller) is now recognised as synonymous with $E$. esculentus (Linnæus) (Mortensen, $5)$, it appears as though the gonadial spicules of $E$. sphora, drawn by Stewart, are not those of E. sphara (Müller) synonymous with E. esculentus (Linnæus).

The walls of the genital tubules near their origin from the genital rachis are densely packed with the typical C-shaped spicules in both $P$. miliaris and E. esculentus.

Spicules appear to be absent from the gonads of Echinocardium cordatum since a dozen freshly preserved specimens from Port Erin showed no trace of these structures.

While considering the spicules of the common Echinoids it may be of interest to note the occurrence of C-shaped spicules, similar to those in the gonad, in the walls of the axial sinus and alimentary canal and in the epithelium lining the test of $E$. esculentus and $P$. miliaris although they are very scarce in the axial sinus of $P$. mitiaris. No record of their occurrence has been met with in the literature consulted. Similar spicules occur in the tube feet of $E$. esculentus as recorded by Chadwick (6). Apart from the perforated plates of the terminal disc, which are similar to those of $E$. esculentus, spicules appear to be absent from the tube feet of $P$.miliaris. A careful examination of 50 tube feet from several fresh specimens of this species did not reveal any of these structures.

The foregoing observations indicate that the distribution of the C-shaped spicules in both species is the same as that of the coelomic epithelium. Chadwick (6), however, clearly states that the spicules of the tube feet of $E$. esculentus lie in the connective tissue.

The abundance of spicules varies in different parts of the individual. 
They are most plentiful in the walls of the gonad and alimentary canal and less abundant in the epithelium lining the test and covering the axial sinus.

If, as it may be surmised, the function of the spicules is to support the structures with which they are associated, then their distribution is as one might expect. As the gonads develop and increase in size and weight, a considerable pressure will be set up against the epithelium enveloping the gland. The latter must of necessity stretch. As it does so its spicules become scattered, but will still serve to support the distended wall until the gonad is ripe. After the escape of the germ cells the epithelium will contract and so bring the spicules together in dense groups such as are characteristic of the spent gland. The spicules in the walls of the alimentary canal may likewise give support while permitting of a considerable amount of distention. The epithelium lining the test does not perform any particular supporting function and one would expect the spicules therein to be relatively sparse, as in fact they are normally.

All preparations were cleared in glycerine and the appended figures were drawn from such preparations.

These researches were carried out while holding State and Liverpool Education Committee Research scholarships.

My thanks are due to Professor Orton and also to Dr. Mortensen for his courtesy in supplying references to literature, and his assistance in the identification of the small $P$. miliaris from Port Erin.

\section{LITERATURE.}

1. Mortensen, Th. Echinoidea. (i) The Danish Expedition to Siam, 1899-1900. Mém. Acad. Sci., Copenhagen, Sér. \%, t. 1, 1904.

2. Stewart, C. On the Spicula of the regular Echinoidea, pp. 365-371. Transactions of the Linnean Society, Vol. XXV, 1866.

3. Stewart, C. On some Structural Features of Echinostrephus molare, Parasalenia gratiosa, and Stomopneustes variolaris, pp. 909-912. Journal of the Royal Microscopical Society, III, 1880.

4. Stewart, C. On certain organs of the Cidaridæ, pp. 569-572. Transactions of the Linnean Society, Vol. I, Ser. 2, Zoology, 1879.

5. Mortensen, Th. Handbook of the Echinoderms of the British Isles, 1927.

6. Chadwick, H. C. L.M.B.C. Memoirs, No. III. Echinus, 1900. 